Chebaev V. 1958. Chelovek s goryachim serdtsem. Komsomolets Udmurtii, organ Udmurtskogo obkoma VLKSM. 19 noyabrya. (In Russian). \title{
REVISING THE REVOLUTIONARY BIOGRAPHY OF A SARAPUL-BORN MAXIMALIST
}

Abstract. The article addresses the problem of mastering the anthropological approach and the biographical method in studying the events of early Soviet history. This research aimed to reconstruct the life path of a member of the Central Committee of the Baltic Fleet (Tsentrobalt), one of the leaders of the Socialists-Revolutionaries Maximalists Pavel Agafangelovich Krasnopyorov, who was born in Sarapul Prikamye. The study relies on official documents, periodical press of the Russian Civil War period, sources of private origin, including protocols of the Red Guards and Red Partisans committees, publication in such Soviet, Red Army and party newspapers as Volya, Truzhenik and Borba, memoirs of Krasnopyorov's wife A.D. Krasnopyorova-Egorova-Zamytskaya, memoirs of prisoners of the Death Barges P.M. Nevler and A. Ralnikovs and others. Many of sources were first introduced into scientific discourse. The materials and conclusions were compared with historiographic results obtained by other authors. The analysis of historical evidence revealed how Krasnopyorov, who was born in a poor peasant family in the village Chernovo in Arzamastsevsky volost, Sarapul uyezd, Vyatka governorate, Russian Empire, rose to become a statesperson and a party leader at the regional level. Commissioned by Tsentrobalt and Petrosoviet, he actively contributed to the establishment of Soviet power in the Kama region and was killed by his enemies during the Izhevsk-Votkinsk Uprising in October 1918. The findings can be useful for those who study biographies of historical figures of the same period, helping to understand and evaluate their place and role in the socio-political process without bias.

Key words: early Soviet history; Russia; Tsentrobalt; Prikamye; Socialists-Revolutionaries Maximalists; biography; Krasnopyorov.

About the authors: Sergey Lvovich Bekhterev ${ }^{1}$, Doctor of Historical Sciences, Professor at the Department of Theory and History of State and Law; Lyudmila Nikolaevna Bekhtereva ${ }^{2}$, Doctor of Historical Sciences, Chief Researcher, Deputy Director.

Place of employment: ${ }^{1}$ Udmurt State University; ${ }^{2}$ Udmurt Federal Research Center, Ural Branch of the Russian Academy of Sciences.

Статья подготовлена при поддержке Комплексной программы фундаментальных научных исследований УрО РАН, проект № 18-6-6-38.

Бехтерев С.Л., Бехтерева Л.Н. Член Центробалта: к революционной биографии сарапульского максималиста // Вестник Нижневартовского государственного университета. 2019. № 3. С. 62-72.

Bekherev S.L., Bekhereva L.N. A Tsentrobalt member: revising the revolutionary biography of a sarapul-born maximalist // Bulletin of Nizhnevartovsk State University. 2019. No. 3. P. 62-72.

\section{ТАРСКИЙ УЕЗД И ЕГО СЛУЖИЛЫЕ ЛЮДИ В ПЕРВОЙ ТРЕТИ ХVІІІ в.}

Аннотация. В статье исследуется положение Тарского уезда и служилых людей Тарского города в первой трети XVIII в. В процессе написания работы были использованы архивные материалы: ответы администрации Тарского уезда на вопросы анкеты профессора Г.Ф. Миллера, книги и столбцы Сибирского приказа по служилым людям Сибири, а также материалы из фонда Сената. В статье приводятся данные по городу Таре и его уезду в 1730-е гг. Особенностью Тарского уезда являлось его пограничное положение. К югу от уезда находилось крупнейшее государство кочевников ойратов - Джунгарское ханство, знать которого собирала дань с тюрского населения уезда. Реформы Петра I привели к глубоким изменениям в социальном 
мире Сибири. В первой трети XVIII в. происходят значительные изменения в составе населения уезда: из родственников служилого населения и духовенства формируется социальная группа разночинцев, а значительная часть служилых людей Тары переводится на службу в гарнизонные полки Сибири и Оренбургской губернии. Конфликт конных казаков Тары с ротмистром Яковом Чередовым показателен для понимания представлений о службе служилого мира города. Семья Чередовых являлась одной из старых семей русских служилых людей, живших в Таре со времени основания города. Чередовы занимали ряд важных постов в служилом мире Тары, многие из них стали детьми боярскими и дворянами. После событий так называемого Тарского бунта 1722 г., в котором Чередовы приняли значительное участие, Чередовы утратили свое привилегированное положение и стали разночинцами Тары. Служилые люди «старых служб» - дворяне, дети боярские, казаки - и после реформ остались главной военной силой в уездах Сибири, однако увеличилась зависимость этой группы от государства. Новые гарнизонные полки в крае формировались в 1730-е гг. главным образом из старых служилых людей.

Ключевые слова: дети боярские; конные казаки; служилые люди; губернатор; уезд; город.

Сведения об авторе: Владимир Дмитриевич Пузанов, доктор исторических наук, профессор кафедры истории и права.

Место работы: Шадринский государственный педагогический университет.

Контактная информация: 641870, Россия, г. Шадринск, ул. Карла Либкнехта, д. 3; тел. 89195720716, e-mail: alan1971@bk.ru.

В XVIII в. из городов - центров уездов Сибири военные силы постепенно были переведены на особые линии укреплений, защищавшие южные границы края. В 1715 1720 гг. русскими войсками в результате нескольких экспедиций по указу Петра I были построены крепости Иртышской линии. В 1763 г. к югу от Иртышских крепостей началось строительство укреплений Бухтарминской линии. Ранее к 1747 г. на российском Алтае возникли укрепления Колыванской и Кузнецкой линий. В 17651770 гг. к востоку от этих старых укреплений были построены новые Колыванская и Кузнецкая линии. В 1752-1756 гг. части русской армии и крестьяне края построили Новую Ишимскую линию, которая защищала от набегов земли Сибирской губернии от Звериноголовской крепости до Омской крепости.

В правление Петра I в Сибири правительство проводит крупные преобразования. По Черепановской летописи, в 1705 г. начались рекрутские наборы в Сибири. В 1706 г. в уездах, острогах и слободах Тобольского разряда были взяты в солдаты с посадских людей, крестьян и бобылей с 20 дворов по человеку (РГАДА. Ф. 196. Оп. 1. Д. 1543. Л. 119). По данным Сибирского приказа, именно в Сибирской губернии в рекруты бралась более значительная часть населения, чем в других губерниях России,
«Сибирская губерния с городов и слобод с купечества и крестьян имеется в переплате рекрут» (РГАДА. Ф. 248. ОП. 8. Кн. 448. Л. 173). Всего, по данным Сибирского приказа, в рекрутские наборы с 1703 по 1721 гг. из Сибирской губернии было набрано 23642 человека. В результате Сибирский приказ отмечал в 1732 г., что «во многих городах и уездах к поселению людей удобных мест имеется довольно, но токмо Сибирская губерния людьми весьма малолюдна» (РГАДА. Ф. 248. Оп. 8. Кн. 448. Л. 173).

Однако в целом внешне города Сибири в первые десятилетия XVIII в. мало изменились по сравнению с эпохой первого столетия русской колонизации края. Одним из важных южных городов Сибирской губернии был уездный город Тара, откуда открывался путь на юг в новые, построенные в 1715-1720 гг., Иртышские крепости. Тара в XVII-XVIII вв. являлась важным центром внешней торговли Сибири с Джунгарией, Китаем и Бухарой. По данным анкеты, посланной администрацией Тарского уезда профессору Г.Ф. Миллеру в 1734 г., и в это время город Тара был огорожен стоячим острогом, «да в том же городе имеется малой город», который также был «огорожен стоячим же острогом и у того малого города имеется проезжая шатровая башня с воротами, на которой имеются соборной 
церкви колокола». В «малом городе» имелась «казенного строения» соборная церковь во имя Успения Пресвятой Богородицы с приделом во имя Сергия Радонежского чудотворца. В городе также находились административные здания - тарская воеводская канцелярия, в ней теплые 3 «жила», «казенный соболиный анбар», в котором лежали запасы «зборной государевой ясашной казны» (РГАДА. Ф. 199. П. 481. Ч. 4. Л. 1). В «большом городе» Тары имелись 3 церкви, таможня и «при той таможне гостиной двор».

Городские стены Тары были усилены рвом и валом. Под городом около «верхнего посада» имелся ров глубиной на 1,5 apшина, а шириной в 2 сажени. Подле рва находился вал, «на валу за палисад в столбах забрано заплотом», на рву были построены 3 «проезжие вороты» с 3 башнями, позади рва «надолбы двойные запускные и рогатки новые». В анкете отмечалось, что в городе Таре последний «малой острог» был застроен в далеком 1669 г., а дополнительно укреплен - «в совершенство приведен» в 1677 г. В 1713 г. «всеми тарскими градскими и уездными жителями служилыми людьми и разночинцами и татарами для осторожности от набегов неприятельских людей» на горе «около всего тарского жительства» был построен земляной вал и вырыт ров (РГАДА. Ф. 199. П. 481. Ч. 4. Л. 5). В городе имелась серьезная артиллерия. Всего в Таре к 1734 г. имелись 10 пушек чугунных весом в 19-20 пудов, а также 3 пушки «полковые походные» весом в 2-3 пуда, и 8 «пищалей затинных весом» по одному пуду (РГАДА. Ф. 199. П. 481. Ч. 4. Л. 18-21).

В городе Таре к 1734 г. имелось 622 двора - 1 «казеппой двор», в котором жил воевода, дворы духовенства - 1 двор протопа, 3 двора «поповских», 2 двора дьяконов, 1 двор пономарский. Много дворов принадлежало служилым людям - 16 дворов приказных служителей, 1 двор майорский, 4 двора дворян и детей боярских, 1 двор казачьего головы, 60 дворов конных казаков, 109 дворов пеших казаков, 19 дворов отставных солдат и казаков. В городе имелось также 65 дворов посадских людей и 298 дворов «разночинцев, которые платят подушные деньги», 3 двора «оброчных бобылей, которые за десятинную пашню платят оброчной провиант», 5 дворов ямщиков, 2 двора служилых татар, 6 дворов ясачных татар и 23 двора бухарцев (РГАДА. Ф. 199. П. 481. Ч. 4. Л. 21-22).

К Тарскому уезду принадлежали и были «приписаны» новые, построенные по указам Петра I на р. Иртыш, Омская, Железинская крепости, а также Аевская, Бергамацкая, Татмыцкая, Чернолуцкая слободы и ясачные волости по р. Иртышу. В год с населения Тарского уезда собиралось «всякой казны» подушных денег 6206 руб. 21 коп. - с посадских и цеховых 188 руб. 40 коп. по 1 руб. 20 коп., с разночинцев, крестьян, дворовых людей, с присыльных 7 гривенных 3961 руб. 41 коп., с 4 гривенных 2056 руб. 40 коп. Кроме того, с ясачных волостей «ясачной казны разной мягкой рухляди по окладу» собиралось всего на 1991 руб. 50 коп., с тарских юртовских бухарцев, с отставных служилых татар и детей 24 руб. 90 коп. В результате к 1734 г. «всего казны збирается» с Тарского уезда на 8222 руб. 61 коп. (РГАДА. Ф. 199. П. 481. Ч. 4. Л. 3 ).

К югу от Тарского уезда начинались владения могущественного государства кочевников - Джунгарского ханства. Большой проблемой в отношениях Российской империи и Джунгарии являлось отсутствие определенной и признанной границы между этими государствами (Бобров 2015: 637). Правители Джунгарии считали своими данниками и собирали алман с многих волостей тіорского паселепия сибирских Тарского и Кузнецкого уездов. В анкете 1734 г. на вопрос «какие барабинские волости дают ясак или алман калмыкам?», власти Тары отвечали, что на 7 барабинских волостей «положен ясак изстари», а оклады ясачные люди имели разные, так, с Тунуской волости собирали 54 лисицы и 2 вы- 
дры, с Любанской - 14 лисиц и 2 выдры, с Кулебинской - 44 лисицы и 2 выдры, с Карагалинской - 14 лисиц и 2 выдры, с Барабинской - 124 лисицы и 15 выдр, с Чойской - 56 лисиц и 4 выдры, с Теренинской - 18 лисиц и 4 выдры (РГАДА. Ф. 199. П. 481. Ч. 4. Л. 47).

Далее в анкете администрация Тары сообщала о том, как собирали алман сборщики джунгар: «А насколько де ценою оных зверей про то де не знают, а оной де ясак называется алманом по их ойратскому названию, а они де барабинцы называют ясаком, а приезжают по оной ясак от оного владельца Галдан Черена зборщики в вешнее время после платежа в казну ясаку збирают означенный ясак по окладу, а ежели промыслу лисиц и выдр не будет, то збирают другими разными зверьми за каждую лисицу по 2 корсака, или по полукоже красной или по 2 бобра небольшие, а за каждую выдру по 4 лисицы или по 2 кожи красных, только неведомо по приказу означенного Галдан Черена или собою оные зборшики берут сверх оного ясачного оклада на себя корму» по 17 скотин да хлеба по 8-10 мешков, а за мешок хлеба берут по 5 горностаев, и на лошадей корм... случается, что и более окладного ясаку оные зборщики збирают» (РГАДА. Ф. 199. П. 481. Ч. 4. Л. 48). Таким образом, русские власти фактически признавали зависимость тюркского населения южных уездов не только от Российской империи, но и от ойратов.

Огромные пространства разделяли небольшие русские города Сибири. От города Тары до ближайшего уездного центра на востоке - города Томска считалось в XVIII в. 850 верст. От Томска до уездного города Кузнецка, который более ста лет был паиболее гожшым российским форпостом в Западной Сибири, насчитывалось 365 верст (РГАДА. Ф. 199. П. 481. Ч. 4. Л. 123).

Из Тары несколько сотен служилых людей не могли защитить от набегов кочевников с юга всю территорию уезда. В 1630 г. по грамоте из Москвы в «низовых ясачных волостях» было велено построить острожки и для защиты посылать служилых людей. В 1630 г. в уезде были построены Коурдацкий, Ишимский и Тебендинский остроги «для осторожности в те годы от набегов татарских, и с того году постройки оных острошков служилые люди на годовую службу из города Тары в оные острошки посылано служилых людей по 10 человек». Позднее в Тарском уезде были построены форпосты - Болшерецкий форпост вверх по р. Иртышу на устье речки Бызовки на левом берегу в 97 верстах от города Тары, а также Ейский форпост «вверх по р. Оми на правой стороне той реки Оми в Ейском острову между двумя речками расстоянием от города Тары в 70 верстах» (РГАДА. Ф. 199. П. 481.Ч. 4. Л. 10). На юге в Тепиашской деревне, от города Тары вниз по р. Иртышу на расстоянии от Тары 100 верст стоял еще один острожек.

В научной литературе были отмечены изменения в жизни служилых людей Сибири с начала XVIII в. Так, М.О. Акишин отмечал в качестве новой тенденции эпохи, что с начала XVIII в. Сибирский приказ меньше слушал челобитные служилых людей, а в уездах воеводы и начальные люди меньше считались с войском (Акишин 1996: 20). В ноябре 1706 г. конные казаки города Тары били челом государю в Сибирский приказ и просили отобрать у ротмистра Якова Чередова право суда над ними, полученное ротмистром в 1706 г. Казаки писали, что деды и отцы их, и они сами служили государеву службу и были послушны прежним ротмистрам и Якову Чередову, но судимы были у воеводы в приказной избе. Казаки просили, чтобы их судили в приказпой избе, «чтобы нам от иных чинов в судех разных не быть» (Акишин 1996: 19; РГАДА. Ф. 199. П. 481. Ч. 4. Л. 93 об.).

Яков Александров сын Чередов был представителем старой служилой семьи города Тары. В списке служилых людей Тары 1689 г. первым среди военных отмечен 
представитель этой семьи Александр Чередов, который был верстан в службу на Таре еще в 1642 г. и с этого времени был участником многих военных походов, когда служилые люди преследовали группы кочевников на юге уезда, Кучумовичей, участвовал в караулах и защите ясачных людей уезда. Так в 1660 г. сын боярский Тары Александр Чередов сражался с кочевниками на юге Тарского уезда, а затем отправился за ними в погоню за р. Омь. В 1660 г. Александр Чередов был назначен поручиком и командиром роты рейтар города Тары из сформированного в Сибири воеводой князем И.А. Хилковым рейтарского полка (РГАДА. Ф. 214. Кн. 955. Л. 5).

По данным списка 1689 г. Александру Чередову в это время было уже 70 лет, но он еще служил по городу и упоминался первым среди детей боярских Тары. В 1642 г. оклад Александра составлял 7 руб., 3 чети ржи, 2 чети овса, 2 пуда соли, к 1688 г. денежный оклад был увеличен воеводами города «по государевым грамотам» до 16 руб. Как отмечалось в списке служилых людей Тары, отец Александра Влас Чередов и дед Агапит были присланы на Тару в самом начале ее образования - «город ставить». Таким образом, семья Чередовых служила в городе с 1594 г., когда Тара была основана экспедицией под командой князя Андрея Елецкого (Солодкин 2011: 60). Отец Александра Чередова конный казак, а позднее атаман Тары Влас Колашников, который в 1651 г. стал сыном боярским и позднее отмечался в документах как Влас Чередов (Крих 2016: 23-24).

Александр Чередов вырастил до зрелого возраста семь детей мужского пола. Из них старший Дмитрий служил в детях боярских, Яков - в ротмистрах, Афапасий в сотниках, Никита - в детях боярских, Борис возрастом в 35 лет служил несколько лет в ротмистрах, но был отставлен. Алексей в 30 лет и Михаил в 20 лет были не верстаны в службу (РГАДА. Ф. 214. Кн. 955. Л. 6).
Старший из сыновей Александра Дмитрий был верстан в дети боярские Тары воеводой Михаилом Измайловым в 1657 г. В 1689 г. ему было 50 лет от роду. В 1665 г. Дмитрий Чередов был верстан из детей боярских в рейтарские поручики и затем служил с рейтарами в Тобольске (РГАДА. Ф. 214. Ст. 367. Л. 769 об.). В 1668 г. Дмитрий был назначен ротмистром воеводой Тобольска Петром Годуновым и позднее командовал полуротой рейтар, посланных на Тару, после роспуска рейтарского полка Тобольского разряда (РГАДА. Ф. 214. Ст. 100. Л. 58-121).

В 1677 г. ротмистр Дмитрий Чередов командовал служилыми людьми в походе на юг р. Иртыш. В 1688 г. Дмитрий Чередов был на Москве вновь верстан в дети боярские по городу Таре с большим окладом из оклада татарского головы Тары в 16 руб. денег, 16 чет ржи и 16 чет овса. Сын Дмитрия Яков в 1682 г. был верстан в дети боярские Тары по «государеву указу» и решению воеводы Тобольска А.А. Голицына, получив оклад своего отца (РГАДА. Ф. 214. Кн. 955. Л. 18).

В Сибирском приказе выписали, что 19 января 1688 г. бил челом государю сын боярский города Тары Яков Чередов о пожаловании ему чина ротмистра литовского списка и казаков на Таре, которым ранее служил представитель другого известного рода служилых людей города Степан Немчинов. По челобитной Якова Чередова, Степан Немчинов был отставлен от чина ротмистра, потому что его назначение воеводой Тары не было утверждено Сибирским приказом, «для того что верстан из казаков по воеводскому верстанию». Ротмистр литовского списка на Таре в это время получал хороший оклад в 15 руб. денег, 15 чет ржи, 15 чет овса и 3 пуда соли.

21 января 1706 г. Яков Чередов бил челом, что служит в ротмистрах у конных казаков лет с 19, а памяти ему не дано, чтобы великий государь велел дать ему в Сибирском приказе память против тобольских и иных городов начальных людей. 6 февра- 
ля 1706 г. по государеву указу и приговору князя М.П. Гагарина было велено дать ротмистру Тары наказную память (РГАДА. Ф. 214. Кн. 1464. Л. 94). Чередов «по памяти» должен был взять списки роты у старого ротмистра, пересмотреть казаков на лицо, и ружье у казаков и подать список воеводе, кто явится с каким ружьем. $\mathrm{B}$ компетенции ротмистра находились дела по искам до 15 рублей казаков его отряда, по делам на сумму выше 15 рублей ротмистр должен был обратиться к воеводе.

Однако служба Якова Чередова вызвала недовольство казаков. 10 января 1707 г. 325 казаков города Тары обратились к государю с челобитьем о назначении нового ротмистра. По данным казаков, с 1692 г., когда они служили под началом Якова Чередова, конные казаки не догоняли в погоне воровских воинских людей, грабивших в уезде. Надо отметить, что служба казаков Тары продолжалась на южных заставах уезда с 1 мая по 1 сентября в «работное время», когда им надо было заниматься обычным трудом в своих хозяйствах. Казаки также жаловались, что ротмистр не созывал совет служилых людей сотников, пятидесятников и рядовых казаков для решения вопросов службы, «вся служба без совета войскового». 3 февраля 1707 г. первый губернатор Сибири князь М.П. Гагарин слушал с выписи и приказал передать тарских конных казаков судом и расправой воеводе по-прежнему (РГАДА. Ф. 214. Кн. 1464. Л. 55-56).

В 1707 г. М.П. Гагарин приказал выбрать нового ротмистра к конным казакам города Тары из детей боярских «человека добраго», который советовался бы с казаками, «поступал с ними служилыми людьми с общаго согласия, потому что без согласия в воинском случае бывает государевым ратным людям урон». При этом и ротмистр Яков Чередов должен был остаться в «старом окладе».

9 апреля 1707 г. Чередов писал в челобитной, что он 20 лет служит полевые и отъезжие службы, был послан много раз со служилыми людьми на ойратов и казахов «и на тех боях ранен». Чередов отмечал, что ранее во время долгой службы на него не жаловались служилые люди, а только в 1706 г. на него «били челом» казаки Тары. Чередов просил допросить в Сибирском приказе казаков, подавших жалобу, какие от него были обиды и налоги. Пятидесятник Никифор Гребеневский и казак Матвей Никифоров показали, что Яков Чередов к «расправным делам незаобычен», и из-за этого казаки боялись разорения, поскольку он высылает их «в поле без нужды», когда там нет кочевников. По мнению казаков, Чередов «был незаобычен» и к воинскому делу, в походе до Татмыцкой слободы Чередов бил тяжко батогами казака Григория Рябова «напрасно, за то, что он поверстан в братнее место в казаки, а Якову никаких подарков не дал». За 2 года до того в походе ротмистр бил батогами «напрасно»конного казака Антипу Некрасова (РГАДА. Ф. 214. Кн. 1464. Л. 248-249).

В свою очередь, Чередов сообщил о походах казаков 1693, 1698, 1699, 1700, $1704,1705,1706$ гг. под его началом на юге Тарского уезда для борьбы с кочевниками. В показаниях Чередов рассказал интересные сведения о служилом мире Тары. Правительство давно вело борьбу с практикой найма служилыми людьми гулящих людей, которым служба «не за обычай». По данным ротмистра, непорядки в службе чинили служилые люди: «иные бывают в отъездах для торгового промыслу» в Китайском государстве по 2, 3 и даже 5 лет, а за себя нанимают людей посторонних, которые не обычны к службе, иные старые и увечные, а иные за себя посылают в бой своих холопов». Такое поведение казаков и побуждало Чередова к паказапиям служилых людей. Так, казака Григория Рябова ротмистр велел бить батогами за то, что он явился на смотре в Татмыцкой слободе с плохим ружьем, а не ради своих прихотей, и били его «слегка». Антипу Некрасова велел бить за то, что он, отставной конный казак, служил в походе на юг по Иртышу «за своего 
сына», а его сын в то время нанялся в экспедицию на озеро Ямыш за другого пешего казака. Казак Григорий Степанов сказал на ротмистра «изменное дело», воевода провел сыск у служилых людей, но не нашел никаких подтверждений и отпустил Чередова, «что до него дела нет» (РГАДА. Ф. 214. Кн. 1464. Л. 249). Эти данные ротмистра показывают всю сложность отношений власти и служилого мира на далекой сибирской окраине. Понятно желание служилых людей Сибири служить «по старине». Однако после таких показаний о деятельности служилых людей более понятными становятся и действия правительства Петра I по строительству регулярной армии. Правительство, выплачивая служилым людям жалование и предоставляя им различные льготы, рассчитывало на них как на основную военную силу в государстве. А многие служилые люди, получая жалование, нанимали на свое место наемных людей, занимались промыслами, торговали даже в Китае.

11 июня М.П. Гагарин велел послать на Тару к Семену Карпову «разыскать» про поступки служилых людей города и писать в Москву, а Чередову быть ротмистром до указа, но без суда и расправы над казаками. 15 февраля 1707 г. Яков Чередов был пожалован в дворяне по просьбе его «за многие службы» с прежним окладом (РГАДА. Ф. 214. Кн. 1464. Л. 111). Однако в итоге 1708 г. М.П. Гагарин удовлетворил челобитную казаков Тары и назначил ротмистром казаков литовского списка Ивана Немчинова.

Надо отметить, что и сами Чередовы активно занимались торговлей и промыслами в Тарском уезде. В роду Чередовых в это время имелись сотни десятин земли и 16 дворовых людей (Крих 2016: 33). Род Чередовых и после этой оставки не утратил своей роли в служилом мире Тары. Позднее дворянство получили и другие представители семьи Чередовых, которые выполняли важные поручения, дипломатические и военные, правительства в Сибири. В 1713 г. тарский казачий голова Иван Чередов был послан Гагариным к контайше джунгар для решения спорных территориальных вопросов (Алисов, Гончаров, Ивонин 2014). В 1717 г. губернатор Сибири Гагарин отправил отряд под командой тарского дворянина Василия Чередова по р. Иртыш южнее Ямыштевской крепости лля поиска земель под строительство новых крепостей. Весной 1718 г. Василий Чередов после зимовки на р. Иртыш нашел участок, на котором через несколько месяцев подполковник Ступин начал строить Семипалатинскую крепость (РГАДА. Ф. 196. Оп. 1. Д. 1543. Л. 178-183). В июне 1719 г. тарский дворянин Иван Чередов был отправлен руководителем русской военной экспедиции Иваном Лихаревым посланцем к контайше Джунгарии. В мае 1721 г. Иван Чередов привез в Тобольск посланцев контайши для переговоров с губернатором (РГАДА. Ф. 248. ОП. 1. Кн. 56. Л. 9).

Назначенный губернатором ротмистр Иван Немчинов в 1722 г. стал одним из руководителей служилых людей города в событиях Тарского бунта. Характерно, что и служилые люди рода Чередовых приняли в Тарском бунте активное участие. Религиозные и культурные традиции старообрядчества оказались для Чередовых и многих других служилых людей Тары важнее социального положения и богатства. В итоге дворяне бывший ротмистр Яков Александров, Василий Борисов и Иван Борисов, и дети боярские Степан Афанасьев, Яков Дмитриев и Дмитрий Алексеев Чередовы были в июне 1722 г. посажены под арест, среди 67 служилых людей Тары. После 1722 г. Чередовы утратили чины и свое положение в служилой организации Тары и поздाге стали разпочинцами (Крих 2016: $31,43)$.

Вообще, как отмечала Черепановская летопись, до 1722 г. жители города Тары были «богатейшие из Сибирских городов» за счет торга с калмыками Джунгарии. В ходе следствия по бунту 1722 г., которое проводил вице-губернатор А.К. Петрово- 
Соловово, известный своим «лихоимством и сребролюбием», жители Тары «претерпели немалое разорение» и во многом утратили свое прежнее положение в Сибири (РГАДА. Ф. 196. Оп. 1. Д. 1543. Л. 210 об.).

В XVII в. Тара была одним из главных военных центров Сибири. В 1625 г. в городе служили 421 чел. служилых людей, к 1638 г. их количество выросло до 734 чел. В 1685 г. на Таре служили 730 служилых людей. В 30-е гг. XVIII в. защита города и уезда оставалась делом служилых людей «старых служб». Всего к 1734 г. в Тарском уезде имелось «определенных по штату в службу действительно служащих» 6 чел. дворян, 16 детей боярских, 1 казачий голова, 331 конный казак, 330 пеших казаков, и 21 служилый татарин, всего 705 служилых людей (РГАДА. Ф. 199. П. 481. Ч. 4. Л. 1). Кроме служилых людей в уезде жили и другие группы населения: 120 посадских жителей, 38 цеховых, 4882 разночинца, 537 крестьян и дворовых людей, 259 присыльных, 329 юртовских бухарцев, 261 отставной служилый, их дети и захребетные татары, всего не служащих 6432 чел. (РГАДА. Ф. 199. П. 481. Ч. 4. Л. 2).

Значительные суммы тратились на жалованье военным. Служилые люди получали в годовое жалованье - 6 дворян по 9 руб. человеку, 16 детей боярских по 8 руб., казачий голова 13 руб., казаки конные 331 чел. по 7 руб., казаки пешие 330 чел. по 4 руб., служилые татары «по разным окладам» 172 руб. 25 коп., а всего «служилый город» 4004 руб. 25 коп. Кроме того, часть служилых людей получала и хлебное жалованье. Так, 5 дворян получали хлебное жалование ржи и овса по 5 чет. итого 25 чет. ржи и 25 чет. овса. 12 детей боярских, 150 коншых казаков, 170 пеших казаков получали всего ржи по 3 чет., круп полтора четверика, итого 996 чет ржи, 62 чет. 2 четверика круп. Всего на Таре служило «за хлебное жалование с пашни» служилых людей 118 конных казаков, 157 пеших казаков, 20 служилых татар (РГАДА. Ф. 199. П. 481. Ч. 4. Л. 9-10).
Реформы Петра Великого зачислили тысячи родственников служилых людей и духовенства сибирских городов в особую категорию - разночинцы. В Таре к 1734 г. жили 1318 разночинцев, 44 дворовых, 4 оброчных бобыля, в подгородном уезде в Логиновом погосте 579 разночинцев, 23 дворовых, всего 602 чел., в Ложинковом погосте 650 разночинцев, 2 дворовых, 24 монастырских крестьянина, 6 оброчных бобылей, всего 682 чел., в Знаменском погосте 638 разночинцев, 19 дворовых, 5 бобылей, всего 662 чел.

В целом за первые десятилетия XVIII в. значительно выросло русское население слобод Тарского уезда. После основания Тары и в первой половине XVII в. все русское население Тарского уезда селилось в городе. Во второй половине XVII в. в Тарском уезде началось осторожное строительство слобод. К 1734 г. на территории уезда жили уже тысячи русских семей: в Аевской слободе жили 155 разночинцев, 98 крестьян, всего 253 чел. В Бергамацкой слободе проживали 232 разночинца, 97 крестьян, всего 329 чел., в Татмыцкой слободе - 727 разночинцев, 40 оброчных бобылей, 7 дворовых людей, всего 774 чел., в Чернолуцкой слободе - 228 разночинцев, 151 крестьянин, всего 379 чел. На далеком юге Тарского уезда в присуде Омской крепости к 1734 г. под прикрытием гарнизона проживало уже значительное русское население - 518 разночинцев, 120 крестьян, всего 638 чел. (РГАДА. Ф. 199. П. 481. Ч. 4. Л. 7-8). По данным анкеты, «сверх тех чинов имеется захребетных и отставных служилых татар и их детей» в городе Таре 16 чел., а также бухарцев 40 чел., захребетных татар 3 чел., в Железепгкой крепости 3 чел., в Подгородігом уезде 289 бухарцев, отставных татар 169 чел., захребетных татар 48 чел., всего 565 чел. татарского населения на особых правах - «и оных татар для их иноземства в подушной оклад не положено и подушных денег с них не збирается» (РГАДА. Ф. 199. П. 481. Ч. 4. Л. 8). 
Большие изменения произошли в служилом мире Тары во второй половине 30-х гг. XVIII в. в связи с формированием новых полков на востоке России в Сибири и на Урале. Большие группы служилых людей городов Сибири были посланы на Урал для поддержки Оренбургской экспедиции. По данным анкеты, в 30-е гг. XVIII в. из города Тары служилые люди посылались в Исетскую провинциальную контору для командирования по Оренбургской дороге в крепости по р. Исети по 96 чел. В уезд на Тарские форпосты - Усть-Тарский, Большерецкий, Ейский посылалось по 50 чел., а в Железенскую крепость на p. Иртыш 25 чел. Также для защиты от набегов вниз p. Иртыша в острожки посылалось - в Ишимский по 3 чел., Тебендинский, Коурдацкий, Тепкашский по 2 чел., в слободу Аевскую, Татмыцкую, Бергамацкую по 2 чел. для продажи казенного вина и соли.

В сентябре 1736 г. по указу Сената в Сибири началось формирование гарнизонных войск драгунского полка и солдатского батальона, в которые были направлены сотни служилых людей из городов края. К 1741 г. на Таре по штату было дворян 6 чел., из них выбыло 5 чел., остался 1 чел., из 16 детей боярских выбыло 5 чел., осталось 11 чел. с жалованием по 7 руб. В уезде по штату служило 331 чел. конных казаков с головою и 21 чел. служилых татар, всего 353 чел. Из них 63 чел. служилых людей были зачислены в Оренбургский полк, а 53 чел. - в формируемые в Тобольске части драгун и солдат, кроме того 5 чел. казаков и
1 служилый татарин умерли. В результате из конных казаков Тары выбыли 122 чел., и в корпорации осталось только 229 чел. В городе в корпорации пеших казаков состояло по штату 330 чел., из которых 42 чел. были зачислены в Оренбургский полк, а 15 чел. попали в драгуны и солдаты Тобольска. Кроме того, 2 казака бежали, а 6 чел. умерли, в итоге из корпорации выбыли 65 чел., осталось 265 чел. В целом потери служилых людей Тары были значительны: из 683 чел. «всего казаков» по штату выбыли в полки, бежали и умерли «без замены» 187 чел. В казаках города Тары осталось только 496 чел.

В 30-е гг. XVIII в. в слободах Тарского уезда появились и отряды регулярного войска. В Татмыцкой слободе Тарского уезда находилась команда Новоучрежденного тобольского драгунского полка, в которой служили прапорщик и 51 чел. драгун, а также поручик Иван Белоусов и 38 чел. солдат Новоучрежденного тобольского батальона (РГАДА. Ф. 199. П. 481. Ч. 4. Л. 37-38).

Реформы Петра I привели к глубоким изменениям в социальном мире Сибири. Служилые люди «старых служб»- дворяне, дети боярские, казаки и после реформ остались главной военной силой в уездах Сибири, однако увеличилась зависимость этой группы от государства. Новые гарнизонные полки в крае формировались в 1730-е гг. главным образом из старых служилых людей.

\section{СПИСОК СОКРАЩЕНИЙ}

РГАДА - Российский государственный архив древних актов

\section{ЛИТЕРАТУРА}

Акиนин М.О. 1996. Полицейское государство и сибирское общество. Эпоха Петра Великого. Новосибирск: Автор.

Алисов Д.А., Гончаров Ю.М., Ивонин А.Р. 2014. Тара в XVI-XIX вв. - российская крепость на берегах Иртыша / С.А. Алферов (отв. ред.). Омск: Амфора.

Бобров Д.С. 2015. Стратегическая государственная граница Российской империи на юге Западной Сибири в первой половине XVIII в. // Русь, Россия. Средневековье и Новое время 4, 635-639.

Kpux A.A. 2016. Русское население Тарского Прииртышья: историко-генеалогические очерки (XVII начало XX в.). Омск: Наука. 
Солодкин Я.Г. 2011. Вослед Савве Есипову. Очерки сибирского летописания середины - второй половины XVII в. Нижневартовск: Изд-во НВГУ.

РГАДА. Ф. 196. ОП. 1. Д. 1543.

РГАДА. Ф. 199. П. 481. Ч. 4.

РГАДА. Ф. 214. Кн. 955.

РГАДА. Ф. 214. Кн. 1464.

РГАДА. Ф. 248. Оп. 1. Кн. 56.

РГАДА. Ф. 248. ОП. 8. Кн. 448.

РГАДА. Ф. 214. СТ. 100.

РГАДА. Ф. 214. Ст. 367.

\title{
REFERENCES
}

Akishin M.O. 1996. Politseiskoe gosudarstvo i sibirskoe obshchestvo. Epokha Petra Velikogo. Novosibirsk. (In Russian).

Alisov D.A., Goncharov Yu.M., Ivonin A.R. 2014. Tara v XVI-XIX vv. - rossiiskaya krepost' na beregakh Irtysha. Omsk. (In Russian).

Bobrov D.S. 2015. Strategical state frontier of Russian Empire in the southern Siberia in the first half of XVIIIth century.In Rus', Rossiya. Srednevekov'e i Novoe vremya, 4, 635-639. (In Russian).

Krikh A.A. 2016. Russkoe naselenie Tarskogo Priirtysh'ya: istoriko-genealogicheskie ocherki (XVII -nachalo XX v.). Omsk. (In Russian).

Solodkin Ya.G. 2011. Vosled Savve Esipovu. Ocherki sibirskogo letopisaniya serediny - vtoroi poloviny XVII v. Nizhnevartovsk. (In Russian).

RGADA. [Russian State Archive of Ancient Acts. Fund]. F. 196. Op. 1. D. 1543. (In Russian).

RGADA. [Russian State Archive of Ancient Acts. Fund]. F. 199. P. 481. Ch. 4. (In Russian).

RGADA. [Russian State Archive of Ancient Acts. Fund]. F. 214. Kn. 955. (In Russian).

RGADA. [Russian State Archive of Ancient Acts. Fund]. F. 214. Kn. 1464. (In Russian).

RGADA. [Russian State Archive of Ancient Acts. Fund]. F. 214. St. 100. (In Russian).

RGADA. [Russian State Archive of Ancient Acts. Fund]. F. 214. St. 367. (In Russian).

RGADA. [Russian State Archive of Ancient Acts. Fund]. F. 248. Op. 1. Kn. 56. (In Russian).

RGADA. [Russian State Archive of Ancient Acts. Fund]. F. 248. Op. 8. Kn. 448. (In Russian).

V. D. Puzanov

Shadrinsk, Russia

\section{TARSKY DISTRICT AND HIS EMPLOYEES IN THE FIRST THIRD OF THE XVIII CENTURY}

\begin{abstract}
The article examines the situation of Tara uyezd and service people who lived in the town of Tara in the first third of the 18th century. The research relies on such archival materials as responses of officials of Tara uyezd who completed to Prof. G.F. Miller's questionnaire, books and tables of Siberian prikaz on the servitors in Siberia, and materials from the Senate fund. The article provides data on the town of Tara and Tara uyezd in the 1730s. Tara had a near-border position. A large Oirat state -Dzungar Khanate - was located to the south of Tara, and noble Oirat nomads collected tribute from the Turkic population of the uyezd. The reforms of Peter I made profound changes in the social world of Siberia. In the first third of the 18th century, the composition of the uyezd's population was significantly altered. A new social group raznochintsy was formed of the relatives of servitors and clergy, and a large part of Tara's service people were transferred to the garrison regiments of Siberia and the Orenburg governorate. The conflict between Tara's horse Cossacks and captain Yakov Cheredov is indicative and important for understanding the service in favor of the state at that time. The Cheredovs were a deep-rooted clan of Russian service people who had lived in Tara since its founding. The Cheredovs held a number of important offices in Tara, and many of them became Boyar scions and nobles. After the 1722 Tara Rebellion, in which the Cheredovs played a significant role, they lost their privileged position and became raznochintsy. The 'old' service people who were nobles, Boyar scions and Cossacks remained the main military force in Siberian uyezds after the reforms. However, their dependence on the state increased. New garrison regiments in the region were formed in the 1730s, mostly of 'old' service people.
\end{abstract}

Key words: Boyar scions; horse Cossacks; service people; governor; uyezd; town.

About the author: Vladimir Dmitrievich Puzanov, Doctor of Historical Sciences, Professor at the Department of History and Law.

Place of employment: Shadrinsk State Pedagogical University. 